Огляди літератури, оригінальні дослідження, погляд на проблему

УДК 616.152.72:[616.24-007.272+616.61-002.3]-036.1-097-08-035

DOI 10.11603/1811-2471.2018.v0.i1.8590

\title{
ЗМІНИ ПОКАЗНИКІВ ВМІСТУ В КРОВІ ЦИТОКІНІВ ТА ГОМЕОСТАЗУ ЗАЛІЗА ЗА КОМОРБІДНОСТІ ХРОНІЧНОГО ОБСТРУКТИВНОГО ЗАХВОРЮВАННЯ ЛЕГЕНЬ ТА ХРОНІЧНОГО ПІЄЛОНЕФРИТУ В ДИНАМІЦІ КОМПЛЕКСНОГО ЛІКУВАННЯ
}

\author{
○К. В. Вілігорська, О. С. Хухліна, В. С. Гайдичук \\ ВДНЗ України “Буковинський державний медичний університет», м. Чернівці
}

РЕЗЮмЕ. Вступ. Згідно з рекомендаціями керівництва з діагностики та лікування хронічного обструктивного захворювання легень (ХОЗЛ) - Global Initiative for Chronic Obstructive Lung Disease (GOLD), комплексна терапія ХОЗЛ та супутніх захворювань, особливо ниркової системи, таких, як хронічний пієлонефрит (ХП), сечокам'яна хвороба (CKX), дозволяє краще контролювати загострення та запобігати ускладненням. За такої коморбідності хронічне запалення провокує підвищення рівня інтерлейкінів $-1 \beta, 6$ (ІЛ-1ß,6), що впливає на зниження рівня транспортних форм заліза - феритину, трансферину, призводячи до клініки сидеропенічного синдрому. Патогенетичні особливості коморбідного ХОЗЛ та ХП $є$ недостатньо вивченими та потребують детального розгляду для досягнення кращих результатів лікування.

Мета - визначення змін показників цитокінового профілю та транспортних форм заліза у пацієнтів із коморбідним ХОЗЛ, ХП та СКХ у динаміці комплексного лікування комбінованим препаратом магнію та піридоксину.

Матеріал і методи. Обстежено 37 пацієнтів із хронічним обструктивним захворюванням легень, хронічним пієлонефритом та сечокам'яною хворобою різного ступеня тяжкості. Пацієнти були поділені на 2 групи дослідження залежно від отриманого лікування. Окрім стандартного лікування хворі основної групи дослідження отримували терапію препаратом магнію лактату дигідрату 470 мг та піридоксину гідрохлориду 5 мг. Був проведений порівняльний аналіз рівнів інтерлейкінів-1ß та 6, транспортних форм заліза до та після лікування.

Результати. В результаті проведених досліджень цитокінового профілю і показників метаболізму заліза у пацієнтів із коморбідними ХОЗЛ, ХП та СКХ, які доповнювали базисну терапію прийомом препарату магнію лактату дигідрату та піридоксину гідрохлориду, було зареєстровано підвищення рівня сироваткового заліза у $1,6$ раза $(p<0,05)$, порівняно із показниками до лікування, та зниження рівнів ІЛ-1 $\beta$ та 6 у 2,0 рази ( $<<0,05)$. Покращення самопочуття пацієнтів, позитивна зміна клінічної картини коморбідної патології ХОЗЛ та ХП свідчить про відновлення процесів утворення та транспорту заліза.

Висновки. Доповнення стандартної терапії препаратом магнію та піридоксину у пацієнтів із ХОЗЛ та ХП сприяє нормалізації рівня цитокінів, рівнів сироваткового заліза, феритину, покращенню клінічного перебігу захворювань, що вказує на доцільність застосування комплексного препарату магнію та піридоксину у таких пацієнтів.

КлючОВІ СлОВА: хронічне обструктивне захворювання легень; пієлонефрит; інтерлейкіни; сечокам'яна хвороба; магній.

Вступ. Важливу роль у прогресуванні багатьох захворювань внутрішніх органів відіграють про- та протизапальні цитокіни [1]. Для хронічного обструктивного захворювання легень (ХОЗЛ) характерна наявність стійкого системного запального процесу, про який свідчить циркуляція в крові відповідних біомаркерів: інтерлейкінів $-1 \beta$, $6,8$ (ІЛ-1 $\beta, 6,8)$, фактора некрозу пухлин-а, С-реактивного білка. За даними вітчизняних дослідників, зниження функціональної здатності легень при ХОЗЛ відбувається з вищою інтенсивністю та асоціюється із підвищеним рівнем ІЛ-6 у мокротинні та великою кількістю нейтрофілів і фібриногену в плазмі крові. Медіатори запалення, які циркулюють у крові, з часом можуть призвести до втрати м'язової маси, посилювати перебіг супутніх захворювань [2]. Коморбідність ХОЗЛ із захворюваннями нирок потребує особливої уваги в світлі навантаження на резервні можливості організму загалом, а саме наявність хронічного пієлонефриту (ХП) доповнює системний за- пальний процес, який $\epsilon$ частиною патогенезу ХОЗЛ, що створює синдром взаємообтяження. Часто на тлі ХП наявні інші урологічні захворювання, такі як цистит, уретрит, сечокам'яна хвороба (СКХ). В основі розвитку сечокам'яної хвороби лежать порушення метаболізму засвоєння і виведення іонів кальцію, магнію, натрію, їх комплексоутворення, метаболізму сечової та щавлевої кислот $[3,4]$. Конкременти при CKX можуть бути провокуючим фактором рецидивів ХП. Комбінована ниркова патологія при ХОЗЛ навіть при латентному перебігу чинить значний вплив на процеси еритропоезу та гомеостазу заліза. Іншим наслідком запального процесу при коморбідній патології ХОЗЛ та ХП $\epsilon$ розвиток недостатності вітаміну $\mathrm{B}_{6}$, піридоксину та його форм, що негативно впливає на клітинний імунітет, збільшуючи ризик коінфекції, призводячи до частих загострень ХОЗЛ, виснаження запасів магнію, посилення бронхоспастичного компонента бронхообструктивного синдрому (БОС) $[5,6]$. Як зазначено у міжнародно- 
Огляди літератури, оригінальні дослідження, погляд на проблему

му керівництві з діагностики та лікування ХОЗЛ Global Initiative for Chronic Obstructive Lung Disease (GOLD), встановлення та контроль супутніх захворювань при ХОЗЛ, їх комплексне лікування із метаболічною та імуностимулювальною терапією на постійній основі $є$ необхідними для ефективного запобігання ускладненням та загостренням ХОЗЛ [7].

Мета - визначити зміни показників цитокінового профілю та транспортних форм заліза у пацієнтів із коморбідними ХОЗЛ, ХП та СКХ у динаміці комплексного лікування комбінованим препаратом магнію та піридоксину.

Матеріал і методи дослідження. Під час проведення дослідження було обстежено 37 пацієнтів, які, залежно від отриманого лікування, були поділені на дві групи. Групу контролю склали 20 практично здорових осіб (ПЗО). До першої (І), основної групи дослідження, увійшли 19 пацієнтів із ХОЗЛ (2B, 3C, D GOLD), коморбідними ХП та CKX оксалатного генезу, яким, разом зі стандартним лікуванням, призначали препарат, що містив комбінацію магнію лактату дигідрату 470 мг та піридоксину гідрохлодиду 5 мг у таблетованій формі для перорального застосування - "Магнікум" (Київський вітамінний завод) по 1 таблетці 2 рази на добу після їди впродовж 1 місяця. До другої (II), групи порівняння, увійшли 18 пацієнтів, репрезентативних за віком та статтю, які отримували традиційне базисне лікування. Стандартна терапія ХОЗЛ варіювала залежно від групи ХO3Л за GOLD. Для пацієнтів із ХОЗЛ 2В використовували монотерапію $\beta 2$-адреноміментиком тривалої дії формотерол (зафірон, форадил) 12 мкг/дозу по 1 - 2 вдихи 2 рази на добу; для пацієнтів із ХОЗЛ 3C,D - фіксовану комбінацію бронхолітиків тривалої дії з впливом на різні складові бронхообструктивного синдрому (бронхоспазм, інфільтрація та набряк слизової оболонки бронхів запальної природи) фенотерол/ іпратропіум (беродуал Н 20/50 мкг/дозу) 1-2 вдихи 3-4 рази на добу. Згідно з протоколом була призначена муколітична терапія похідними вазицину: бромгексин 8 - 16 мг 2 - 3 рази на добу. Протизапальна терапія для пацієнтів із ХОЗЛ 2 В включала фенспірид (ереспал) 0,08 г двічі на добу, сироп 150 мл (200 мг / 100 мл) - курс лікування - 2-5 місяців; та рофлуміласт (даксас) 0,5 мг 1 раз на добу курс лікування - від 6 місяців та більше для пацієнтів із ХОЗЛ C, D.

Для терапії загострень, в тому числі гнійних, незалежно від групи ХОЗЛ за GOLD, використовували захищені амінопеніциліни: амоксицилін/ клавуланова кислота (флемоклав солютаб, амоксиклав, аугментин) 0,5-1,0 г 3 рази на добу per os або в/в. Тривалість антибактеріальної терапії 5-10 днів.
Середній вік обстежених осіб становив $(55,9 \pm 3,3)$ років. Вік осіб, які склали контрольну групу, становив $(53,5 \pm 3,2)$ років. Відсутність значимих відмінностей за віковими та статевими ознаками між контрольною та групами дослідження дозволяє оцінити їх репрезентативність та підкреслити можливість порівняння показників визначених груп.

Визначення ступеня тяжкості бронхіальної о6струкції та ступеня ризику несприятливого перебігу і лікування ХОЗЛ проводили згідно з наказом МО3 України № 555 від 27.06.2013, враховуючи рекомендації, зазначені в міжнародному документі GOLD. Діагностика та лікування ХП проводились згідно з наказом МОЗ України від 11.05.2011 № 280/44 "Про затвердження стандарту та уніфікованих клінічних протоколів надання медичної допомоги зі спеціальності "нефрологія", додаток 1.2. Наявність СKX та терапевтичну тактику визначали згідно з Наказом № 604 MO3 України від 06.12.2004, “Протокол ведення хворих. Сечокам'яна хвороба. Камені нирки (№20.0)". Враховували наявність симптомокомплексу згідно з відповідними протоколами діагностики ХП та CKX: тіні конкрементів під час ультразвукового дослідження нирок, порушення уродинаміки (розширення порожнинної системи нирки чи певної групи чашок), наявна тривала лейкоцитурія (аналіз сечі за Нечипоренко), оксалатурія.

Дослідження функції зовнішнього дихання проводилося на спірографі “Microlab-3300" ("Sensor - Medics", Нідерланди) у спокої з подальшим комп'ютерним аналізом отриманих результатів. Для визначення зворотності бронхіальної обструкції використовували інгаляційні проби 3 $\beta$-адреноміметиком (беротек Н) у дозі 400 мг.

Критеріями відбору пацієнтів до основної групи дослідження була наявність ХОЗЛ (2B, 3С, 3D GOLD) із коморбідними ХП та CKX оксалатного ґенезу. Діагностування ступеня ХO3Л за GOLD проводилось з врахуванням даних комп'ютерної спірометрії, які оцінювались за класифікацією тяжкості обмеження повітроносних шляхів на основі постбронходилатаційного об'єму форсованого видиху за першу секунду (ОФВ1), присутності симптомокомплексу: експіраторна задишка при фізичному навантаженні, хронічний кашель, погане виділення харкотиння; часті загострення. Тяжкість задишки визначали за модифікованою шкалою задишки "Modified Medical Research Council (mMRC) Dyspnea Scale". Критеріями включення пацієнтів з боку патології нирок була наявність ознак згідно з відповідними протоколами діагностики ХП та СКХ: тіні конкрементів під час ультразвукового дослідження нирок, порушення уродинаміки (розширення порожнинної системи 
Огляди літератури, оригінальні дослідження, погляд на проблему

нирки чи певної групи чашок), наявна тривала лейкоцитурія та оксалатурія, виявлення солей оксалатів кальцію в добовому аналізі сечі.

Критеріями виключення з дослідження були наявність декомпенсованих супровідних захворювань або станів, які можуть суттєво вплинути на результати дослідження: ішемічної хвороби серця, гострого коронарного синдрому, перенесеного інфаркту міокарда, клапанних вад серця, CH II-III стадії (III-IV ФК із фракцією викиду лівого шлуночка нижче 45 \%), цукрового діабету, гострого порушення мозкового кровообігу, ревматологічної патології (ревматичної лихоманки, дифузних захворювань сполучної тканини тощо), онкологічних та інфекційних захворювань, у т. ч. вірусних гепатитів B та C, цирозу печінки різної етіології, психічних розладів, також виключали осіб у період вагітності чи лактації.

Оцінку стану метаболізму заліза проводили згідно з показниками клінічного аналізу крові: кількістю еритроцитів, гемоглобіну в одиниці об' $\epsilon$ му крові, рівня сироваткового заліза (мкмоль/л), трансферину (г/л), феритину (нг/мл). Вміст сироваткового заліза у крові визначали методом калориметричного аналізу з використанням аналізатора Cobas 6000 на тест-системі Roche Diagnostics (Швейцарія). Рівень трансферину визначали імунотурбідиметричним методом на аналізаторі Cobas 6000 (с501 модуль) на тест-системі Roche Diagnostics (Швейцарія), рівень феритину визначали за імунохімічним методом з електрохемілюмінесцентною детекцією (ECLIA) на аналізаторі Cobas 6000 (е 601 модуль) та тест-системі Roche Diagnostics (Швейцарія). Критеріями визначення сидеропенічного синдрому, згідно з наказом МОЗ України від 30.06.2010 № 647 “Про затвердження клінічних протоколів надання медичної допомоги хворим зі спеціальності “Гематологія”, додаток "Клінічний протокол надання допомоги хворим на залізодефіцитну анемію" були наступні симптоми: блідість шкіри та слизових оболонок, тахікардія, зниження концентрації сироваткового заліза (нижче 11,5 мкмоль/л), феритину (нижче 12 мкг/л), трансферину в сироватці крові. Оцінку вмісту цитокінів ІЛ-1ß та ІЛ-6 (пг/мл) у сироватці крові проводили шляхом імуноферментного аналізу (ІФА). Визначення рівня ІЛ-1 $\beta$ за імунохімічним методом з хемілюмінесцентною детекцією (CLIA) проводили на аналізаторі IMMULITE 1000 та тестсистемі Siemens (Німеччина), визначення рівня ІЛ-6 за імунохімічним методом з електрохемілюмінесцентною детекцією (ECLIA) проводили на аналізаторі Cobas 6000 на тест-системі Roche Diagnostics (Швейцарія). Визначення вищезгаданих показників згідно з методиками було проведено на базі лабораторії "Сінево" (м. Чернівці).
Статистичну обробку матеріалу здійснювали за допомогою комп'ютерної програми IBM SPSS Statistics 20 із застосуванням методів варіаційної статистики, визначенням середніх величин (М), середньої похибки (m). Вірогідність змін варіацій в разі нормального розподілу у вибірках визначали за парним критерієм Стьюдента. Вірогідною вважали різницю показників при р<0,05.

Результати й обговорення. Проведений аналіз показників метаболізму заліза та вмісту цитокінів у пацієнтів із коморбідними ХОЗЛ, ХП та СКХ, які $\epsilon$ маркерами порушення еритропоезу та наявності системного запального процесу, показав, що у групі пацієнтів, які доповнювали стандартне лікування прийомом препарату магнію лактату дигідрату та піридоксину гідрохлориду, було зареєстровано підвищення рівня сироваткового заліза у 1,6 раза $(p<0,05)$, порівняно із показниками до лікування (табл. 1), проти 1,2 раза - у контрольній групі, що вказує на відновлення експорту заліза із макрофагів до тканин. Після проведеного лікування у пацієнтів основної групи було встановлено вірогідне підвищення вмісту в крові трансферину у 1,9 раза $(p<0,05)$ та феритину у 4,6 раза $(p<0,05)$, порівняно із показниками до лікування, у контрольній групі зміни вмісту трансферину були невірогідні, а вміст феритину зріс у 2,7 раза $(p<0,05)$ (табл. 1). Це явище відображає активацію розчинних рецепторів до трансферину (soluble transferrin receptor, sTfR), що відповідає за перенос заліза до тканин, які беруть активну участь у процесі еритропоезу. Нормалізація рівня феритину $\epsilon$ свідченням відновлення функціонального дефіциту заліза та запасання цього елементу в депо [8].

Наслідком стимуляції процесів утилізації заліза у пацієнтів основної групи стали вірогідне зростання кількості в крові еритроцитів та гемоглобіну, відповідно у 1,5 та 1,3 раза $(p<0,05)$, у групі порівняння вірогідних змін показників гемограми після проведеного лікування зареєстровано не було.

Підвищення рівня феритину у пацієнтів основної групи супроводжувалось вірогідним зниженням активності ІЛ-1 $1 \beta$ та ІЛ-6, що свідчить про більш ефективну стимуляцію метаболізму заліза у таких пацієнтів, порівняно із тими, які отримували тільки стандартну терапію. У пацієнтів основної групи після проведеного комплексного лікування відзначалось вірогідне зниження рівнів ІЛ-1 $\beta$ та ІЛ-6 у 2,0 рази $(p<0,05)$ порівняно із даними до лікування (табл. 2), що свідчить про зниження системного запального процесу, більшою мірою в паренхімі нирок, а також зниження ендотоксемії [9]. Зниження активності запальної відповіді за рівнем ІЛ-1ß у групі порівняння було у 
Огляди літератури, оригінальні дослідження, погляд на проблему

1,2 раза менш інтенсивним $(p<0,05)$. Рівень прозапального ІЛ-6, який відіграє важливу роль при загостренні ХОЗЛ та ХП, виступаючи транс-сигнальним медіатором відкладання імунних комплексів в паренхіматозних органах $[10,11]$, після проведеного лікування хворих I групи знизився у 1,5 ра- за $(p<0,05) \cdot$ Зазначені зміни маркерів запального процесу та показників обміну заліза супроводжувались покращенням загального самопочуття пацієнтів, зменшенням задишки, головного болю, больових відчуттів у попереку, загальної слабкості.

Таблиця 1. Вміст інтерлейкіну-1ß та інтерлейкіну-6 у крові пацієнтів із ХОЗЛ та коморбідними ХП і CKX

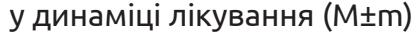

\begin{tabular}{|c|c|c|c|c|c|}
\hline \multirow[t]{2}{*}{ Показники } & \multirow[t]{2}{*}{$\begin{array}{l}\Pi 30 \\
n=20\end{array}$} & \multicolumn{2}{|c|}{$\begin{array}{c}\text { Група порівняння } \\
\text { (стандартне лікування), n=18 }\end{array}$} & \multicolumn{2}{|c|}{$\begin{array}{c}\text { Основна група } \\
\text { (стандартне лікування+магній } \\
\text { і піридоксин), } \mathrm{n}=19\end{array}$} \\
\hline & & до лікування & після лікування & до лікування & після лікування \\
\hline Інтерлейкін-1ß, пг/мл & $2,7 \pm 0,5$ & $5,9 \pm 0,4 *$ & $5,0 \pm 0,2^{*}$ & $5,9 \pm 0,3 *$ & $3,0 \pm 0,3 * / * * / \#$ \\
\hline Інтерлейкін-6, пг/мл & $3,9 \pm 0,3$ & $8,0 \pm 0,5^{*}$ & $5,5 \pm 0,3 * / * *$ & $8,1 \pm 0,4^{*}$ & $4,0 \pm 0,3 * / * * / \#$ \\
\hline
\end{tabular}

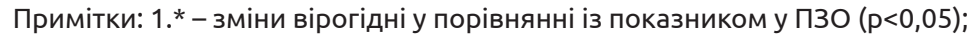

2.** - зміни вірогідні у порівнянні із показниками до лікування;

3. \# - зміни вірогідні у порівнянні із показниками після лікування у хворих I групи.

Таблиця 2. Показники метаболізму заліза у крові пацієнтів із ХОЗЛ та коморбідними ХП і СКХ у динаміці лікування $(\mathrm{M} \pm \mathrm{m})$

\begin{tabular}{|l|c|c|c|c|c|}
\hline \multirow{2}{*}{ Показники } & \multirow{2}{*}{ Пзо } & \multicolumn{2}{|c|}{$\begin{array}{c}\text { Група порівняння } \\
\text { (стандартне лікування), } \mathrm{n=18}\end{array}$} & \multicolumn{2}{|c|}{$\begin{array}{c}\text { Основна група } \\
\text { (стандартне лікування+магній } \\
\text { і піридоксин) }\end{array}$} \\
\cline { 3 - 6 } & & до лікування & після лікування & до лікування & після лікування \\
\hline Еритроцити, Т/л & $5,0 \pm 0,3$ & $3,0 \pm 0,1^{*}$ & $3,3 \pm 0,1^{*}$ & $3,1 \pm 0,1^{*}$ & $4,6 \pm 0,2^{* *} / \#$ \\
\hline Нb, г/л & $125 \pm 9,7$ & $88 \pm 5,0^{*}$ & $91,4 \pm 3,5^{*}$ & $87 \pm 5,2^{*}$ & $109,7 \pm 4,3^{* *} / \#$ \\
\hline $\begin{array}{l}\text { Сироваткове залізо, } \\
\text { мкмоль/л }\end{array}$ & $20,5 \pm 1,6$ & $10,4 \pm 0,4^{*}$ & $12,2 \pm 0,7^{*} / *$ & $10,5 \pm 0,4^{*}$ & $16,9 \pm 0,9 * * / \#$ \\
\hline Феритин, нг/мл & $65 \pm 5,0$ & $11,1 \pm 1,7^{*}$ & $30,3 \pm 2,0^{*} / *$ & $11,3 \pm 1,5^{*}$ & $51,4 \pm 2,5^{* *} / \#$ \\
\hline Трансферин, г/л & $3,5 \pm 0,1$ & $1,8 \pm 0,1^{*}$ & $2,0 \pm 0,3^{*}$ & $1,7 \pm 0,2^{*}$ & $3,2 \pm 0,1^{* *} / \#$ \\
\hline
\end{tabular}

Примітки: 1.* - зміни вірогідні у порівнянні із показником у П3О ( $<<0,05)$;

2.** - зміни вірогідні у порівнянні із показниками до лікування;

3. \# - зміни вірогідні у порівнянні із показниками після лікування у хворих I групи.

До лікуванняупацієнтів Ігрупи рівень лейкоцитурії, згідно з результатами проби за Нечипоренко, був $(4500 \pm 7,9 / м л)(p<0,05)$, II $(4480 \pm 6,3 / м л)(p<0,05)$ проти $(740 \pm 5,81 /$ мл) (р<0,05) у групі П3О. Після лікування було відмічено покращення цього показника в обох групах: у пацієнтів I групи він становив

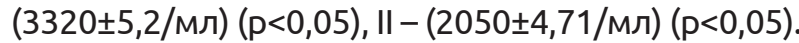

Проведені дослідження виявили ефективність стимулювальної терапії у пацієнтів із ХОЗЛ та ХП препаратом магнію лактату дигідрату та піридоксину гідрохлориду, що підтверджується зниженням активності процесів запалення у пацієнтів цієї групи. Покращення самопочуття пацієнтів основної групи також було позитивною ознакою, яку можна пояснити сповільненням деградації вітаміну $\mathrm{B}_{6}$ через зниження запального процесу. Вітамін $\mathrm{B}_{6} \in$ незамінним ко-фактором у першій ланці синтезу гему, оскільки міститься в амінолевулінатсинтазі, ферменті, який каталізує формування 5-амінолевулінової кислоти в мітохондріальному матриксі. Цю реакцію запускає залізо за допомогою залізо- зв'язуючого білка феритину. Окрім того, піридоксин бере участь в мітохондріальній реакції утворення протопорфірину на заключному етапі синтезу гему $[6,9,10]$.

Висновки. 1. У пацієнтів із хронічним обструктивним захворюванням легень та хронічним пієлонефритом доцільно здійснювати скринінгові дослідження рівня заліза та феритину з метою визначення глибини сидеропенії із подальшою їх корекцією.

2. Додаткове призначення препарату магнію та піридоксину пацієнтам із хронічним обструктивним захворюванням легень та коморбідним хронічним пієлонефритом сприяє зниженню рівнів прозапальних цитокінів ІЛ-1 $\beta$ та ІЛ-6 у 2,0 рази $(p<0,05)$ на тлі нормалізації рівня заліза, феритину, трансферину, покращення клінічного перебігу захворювань.

Перспективи подальших досліджень полягають у поглибленні вивчення впливу метаболізму заліза на результати лікування пацієнтів із хронічним обструктивним захворюванням легень та хронічним пієлонефритом. 
Огляди літератури, оригінальні дослідження, погляд на проблему

\section{ЛІТЕРАТУРА}

1. Palange P. Renal and hormonal abnormalities in chronic obstructive pulmonary disease (COPD) / P. Palange // Thorax. - 1998. - No. 53. - P. 989-991.

2. Фещенко Ю. І. Хронічне обструктивне захворювання легень та супутня депресія - важлива медико-соціальна проблема / Ю. І. Фещенко, Л. О. Яшина, О.В.Поточняк // Український пульмонологічний журнал. 2013. - №3. Додаток. - С. 56-58.

3. Жигунова А. К. Комплексная терапия при дисметаболической нефропатии различного генеза. Роль фитотерапии / Жигунова А. К. // Ліки України. - 2014. № 183-184. - C. 12-22.

4. Skolarikos A. Metabolic evaluation and recurrence prevention for urinary stone patients: EAU Guidelines / A. Skolarikos // European Urology. - 2015. - No. 67 (4). P. 750-763.

5. Franceschi C. Chronic inflammation (inflammaging) and its potential contribution to age-associated diseases / C. Franceschi, J. Campisi // Advances in geroscience: Impact on healthspan and chronic disease perspective. 2014. - No. 69. - P. 4-6.

6. Mydlík M. Metabolism of vitamin B6 and its requirement in chronic renal failure / M. Mydlík, K. Derzsiová, E. Žemberová // Kidney Int. - 1997. - No. 52, Supl. 62. P. 56-59.

\section{REFERENCES}

1. Palange, P. (1998). Renal and hormonal abnormalities in chronic obstructive pulmonary disease (COPD). Thorax, 53, 989-991.

2. Feshchenko, Yu.I., Yashyna, L.O., \& Potochniak, O.V. (2013). Khronichne obstruktyvne zakhvoriuvannia lehen ta suputnia depresiia - vazhlyva medyko-sotsialna problema [Chronic obstructive pulmonary disease and concomitant depression are an important medical and social problem]. Ukrainskyi pulmonolohichnyi zhurnal - Ukrainian Pulmonology Journal, 3, 56-58 [in Ukrainian].

3. Zhyhunova, A.K. (2014). Kompleksnaya terapiya pri dismetabolicheskoy nefropatii razlichnogo geneza. Rol fitoterapii [Complex treatment of dysmetabolic nephropathy of different genesis. The role of phytotherapy]. Liky Ukrainy - Drugs of Ukraine, 7-8 (183-184),12-22 [in Russian].

4. Skolarikos, A. (2015). Metabolic evaluation and recurrence prevention for urinary stone patients: EAU Guidelines. European Urology, 67 (4), 750-763.

5. Franceschi, C., \& Campisi, J. (2014). Chronic inflammation (inflammaging) and its potential contribution to age-associated diseases. Advances in geroscience: Impact on healthspan and chronic disease perspective, 69, 4-6.

6. Mydlík, M., Derzsiová, K., \& Žemberová, E. (1997). Metabolism of vitamin B6 and its requirement in chronic renal failure. Kidney Int., 52, 62, 56-59.

7. From the Global Strategy for the Diagnosis, Management and Prevention of COPD, Global Initiative for Chronic Obstructive Lung Disease (GOLD); 2017. [Inter-
7. From the Global Strategy for the Diagnosis, Management and Prevention of COPD, Global Initiative for Chronic Obstructive Lung Disease (GOLD) 2017. Available from: http://goldcopd.org.

8. Хухліна О. С. Стан системи кровотворення у хворих на хронічне обструктивне захворювання легень та сечокам'яну хворобу / О. С. Хухліна, К. В. Вілігорська // Матеріали науково-практичної конференції «Коморбідність у клініці внутрішньої медицини: фактори ризику, механізми розвитку та взаємообтяження, особливості фармакотерапії», (Чернівці, 10-11 жовтня 2013 р.). Чернівці : БДМУ, 2013. - С. 14-15.

9. Interleukin-6 trans-signaling exacerbates inflammation and renal pathology in lupus-prone mice / E. Tsantikos, M. J. Maxwell, T. Putoczki [et al.] // Arthritis \& Rheumatism. - 2013. - No. 65. - P. 2691-2702.

10. Pyridoxine effect in type I primary hyperoxaluria is associated with the most common mutant allele / C. G. Monico, S. Rossetti, J. B. Olson [et al.] // Kidney International. - 2005. - No. 67 (5). - P. 1704-1709,

11. Van Itallie C. M. Claudins and epithelial paracellular transport / C. M. Van Itallie, J. M. Anderson // Annu. Rev. Physiol. - 2006. - No. 68. - P. 403-429.

12. Rosner B. Fundamentals of biostatistics / B. Rosner. - 6-th ed. - Belmont: Duxbury Press, 2003. - 682 p.

net]; [cited 17 of June 2017]. Available from: http://goldcopd.org.

8. Khukhlina, O.S., Vilihorska, V. (2013). Stan systemy krovotvorennia u khvorykh na khronichne obstruktyvne zakhvoriuvannia lehen ta sechokamianu khvorobu [The state of the erythropoietic system in patients with chronic obstructive pulmonary disease and urolithiasis]. Materialy naukovo-praktychnoi konferentsii "Komorbidnist u klinitsi vnutrishnoi medytsyny: faktory ryzyku, mekhanizmy rozvytku ta vzaiemoobtiazhennia, osoblyvosti farmakoterapii" Materials of the scientific and practical conference "Comorbidity in the clinic of internal medicine: risk factors, mechanisms of development and mutual burden, features of pharmacotherapy". Chernivtsi: BDMU [in Ukrainian].

9. Tsantikos, E., Maxwell, M.J., Putoczki, T., Ernst, M., Rose-John, S., \& Tarlinton, D.M. (2013). Interleukin-6 transsignaling exacerbates inflammation and renal pathology in lupus-prone mice. Arthritis \& Rheumatism, 65, 26912702. doi:10.1002/art.38061

10. Monico, C.G., Rossetti, S., Olson, J.B. (2005). Pyridoxine effect in type I primary hyperoxaluria is associated with the most common mutant allele. Kidney International, 67 (5), 1704-1709, ISSN 0085-2538, http://dx.doi. org/10.1111/j.1523-1755.2005.00267.x.

11. Van Itallie, C.M., \& Anderson, J.M. (2006). Claudins and epithelial paracellular transport. Annu. Rev. Physiol., 68, 403-429.

12. Rosner, B. (2003). Fundamentals of biostatistics, 6-th ed. Belmont: Duxbury Press. 


\title{
Огляди літератури, оригінальні дослідження, погляд на проблему \\ ИЗМЕНЕНИЯ ПОКАЗАТЕЛЕЙ УРОВНЯ ЦИТОКИНОВ И ГОМЕОСТАЗА ЖЕЛЕЗА В КРОВИ ПАЦИЕНТОВ С КОМОРБИДНОЙ ХРОНИЧЕСКОЙ ОБСТРУКТИВНОЙ БОЛЕЗНЬЮ ЛЕГКИХ И ХРОНИЧЕСКИМ ПИЕЛОНЕФРИТОМ В ДИНАМИКЕ КОМПЛЕКСНОГО ЛЕЧЕНИЯ
}

\author{
ОК. В. Вилигорская, О. С. Хухлина, В. С. Гайдичук
}

ВГУЗ Украины «Буковинский государственный медицинский университет», г. Черновцы

РЕзЮМЕ. Введение. Согласно руководству по диагностике и лечению хронической обструктивной болезни легких (ХОБЛ) - Global Initiative for Chronic Obstructive Lung Disease (GOLD), комплексная терапия ХОБЛ и сопутствующих заболеваний, особенно почек, таких, как хронический пиелонефрит (ХП), мочекаменная болезнь (МКБ), позволяет лучше контролировать периоды обострения и предотвращать осложнения. Хроническое воспаление провоцирует повышение уровня интерлейкинов-1 1 , 6 (ИЛ-1 1,6$)$, что влияет на понижение уровня транспортных форм железа - ферритина, трансферина, приводя к клинике сидеропенического синдрома. Патогенетические особенности коморбидности ХОБЛ и ХП еще недостаточно изучены и требуют детального рассмотрения для достижения лучших результатов лечения.

Цель - определение показателей цитокинового профиля и транспортных форм железа у пациентов с коморбидными ХОБЛ, ХП и МКБ в динамике комплексного лечения комбинированным препаратом магния и пиридоксина.

Материал и методы. Обследовано 37 пациентов с хронической обструктивной болезнью легких, хроническим пиелонефритом и мочекаменной болезнью разной степени тяжести. Пациенты были поделены на 2 группы в зависимости от лечения. Кроме стандартной терапии больные основной группы исследования получали терапию препаратом магния лактата дигидрата 470 мг и пиридоксина гидрохлорида 5 мг. Был проведен сравнительный анализ уровней интерлейкинов-1ß и 6, транспортных форм железа до и после лечения.

Результаты. В результате проведенных иследований цитокинового профиля и показателей метаболизма железа у пациентов с коморбидными ХОБЛ, ХП и МКБ, которые дополняли базисную терапию приемом препарата магния лактата дигидрата и пиридоксина гидрохлорида, было зарегистрировано повышение уровня сывороточного железа в 1,6 раза ( $<<0,05)$, по сравнению с показателями до лечения, и снижение уровня Ил-1ß и 6 в 2,0 раза $(p<0,05)$. Улучшение самочувствия пациентов, клинической картины коморбидной патологии, свидетельствует о возобновлении процессов образования и транспорта железа.

Выводы. Дополнение стандартной терапии препаратом магния и пиридоксина у пациентов с ХОБЛ и ХП содействует нормализации уровня цитокинов, сывороточного железа, ферритина, улучшению клинического течения заболеваний, что указывает на целесообразность использования комплексного препарата магния и пиридоксина у таких пациентов.

КЛЮчЕВЫЕ СЛОВА: хроническая обструктивная болезнь легких; пиелонефрит; интерлейкины; мочекаменная болезнь; магний.

\section{CHANGES OF SERUM CYTOKINE AND IRON HOMEOSTASIS INDICES IN PATIENTS WITH CHRONIC OBSTRUCTIVE PULMONARY DISEASE AND CHRONIC PYELONEPHRITIS: COMPLEX TREATMENT DYNAMICS}

\author{
@K. V. Viligorska, O. S. Khukhlina, V. S. Gaydychuk \\ Bukovinian State Medical University, Chernivtsi
}

SUMMARY. Introduction. According to the Global Initiative for Chronic Obstructive Lung Disease (GOLD) guidelines for the diagnosis and treatment of chronic obstructive pulmonary disease (COPD), complex therapy for COPD and comorbid pathologies, especially of the renal system, such as chronic pyelonephritis (CP), urolithiasis (UL) provides better control of exacerbations and prevents complications. In this case chronic inflammation provokes an increase in the levels of interleukins $-1 \beta, 6(I L-1 \beta, 6)$ that affects the levels of transport forms of iron - ferritin, transferrin causing sideropenic syndrome. Pathogenetic features of comorbid COPD and CP have not been studied enough and require detailed examination in order to improve treatment outcomes.

The aim of the study - to determine changes of cytokine profile and iron transport in patients with COPD, CP and UL comorbidity in dynamics of complex treatment with magnesium and pyridoxine supplement.

Material and Methods. 37 patients with chronic obstructive pulmonary disease, chronic pyelonephritis and urolithiasis of different severity were involved. Patients were divided into 2 groups depending on the treatment. In addition to standard treatment, the main study group received therapy with magnesium lactate dihydrate $470 \mathrm{mg}$ and pyridoxine hydrochloride $5 \mathrm{mg}$. A comparative analysis of interleukins- $1 \beta$ and 6 , iron transport forms levels before and after treatment was performed.

Results. Studies of the cytokine and iron metabolism profile in patients with comorbid COPD, CP, and UL who alongside with standard treatment got magnesium lactate dihydrate and pyridoxine hydrochloride supplement showed 
Огляди літератури, оригінальні дослідження, погляд на проблему

an increased level of serum iron 1.6 times more $(p<0.05)$ in comparison to results before the treatment and decreased levels of IL-1 $1,62,0$ times less $(p<0.05)$. Improvement of patients' health state, positive change in clinical signs of comorbid COPD and CP signify a renewal of iron formation and transport.

Conclusions. Completion of standard therapy with magnesium and pyridoxine supplement helps to normalize cytokine levels, levels of serum iron, ferritin and clinical course, so it is advisable to use magnesium and pyridoxine supplementation in such patients.

KEY WORDS: chronic obstructive pulmonary disease; pyelonephritis; interleukins; urolithiasis; magnesium.

Отримано 10.02.2018 